\title{
EFFECT OF TAX REVENUE ON ECONOMIC DEVELOPMENT: EVIDENCE FROM NIGERIA
}

\author{
Ogbodo, Okenwa Cy \\ Department of Accountancy \\ NnamdiAzikiwe University, Awka \\ Mail: cyogbodo2016@yahoo.com \\ Nweze, Chike L. \\ Department of Accountancy \\ NnamdiAzikiwe University, Awka \\ Mail: nwezeleonard@yahoo.com
}

\begin{abstract}
The main objective of this study is to ascertain the effect of Tax Revenue on Economic Development with a focus on Nigeria. The specific objectives were to determine; the effect of Companies' Income Tax on Per Capita Income, Petroleum Profit Tax on Per Capita Incomeof Nigeria from 2000-2019. This study employed the use of time series data and Expost facto research design was adopted. Secondary data were sourced from Central Bank of Nigeria (CBN), Statistical Bulletin, Federal Inland Revenue Service (FIRS), World Bank Statistical Bulletin and Annual Abstract of Statistics from the National Bureau of Statistics (NBS). Inferential statistics of the hypotheses were carried out with the aid of E-views 10 statistical software using Ordinary Least Square (OLS) regression analysis, Granger Causality test. The study found that companies' income tax has a significant positive effect on per capita income of Nigeria; petroleum profit tax has a significant positive effect on per capita income of Nigeria; It was recommended inter alia that federal government of Nigeria should underpin public financial management reforms, strengthen supervisory and transparency practices, improve tax administration, and fight tax evasion.
\end{abstract}

Keywords: Tax Revenue, Economic Development, Income Tax, and Petroleum Profit Tax 


\section{INTRODUCTION}

The economic development of any nation depends on the amount of resources generated and under its control to finance its infrastructural need and meet its day to day expenditure. The resources needed is believed however to be generated from external and internal- through a structured tax system. Economic development is the growth of the standard of living of a nation's people from a low-income (poor) economy to a high-income (rich) economy. When the local quality of life is improved, there is more economic development (Tom ljanocich, 2014). Tax as a macro-economic policy tool determines the level and pace of economic growth in nations of the world. A well-structured tax system offer government opportunity to generate needed revenue to meet its ever growing need. Tax is a veritable and sustainable source of revenue for government and a tool for fiscal policy and macro-economic management. It is a potential tool for economic and social reform as it pervades all aspect of the economy, individual, companies, citizens and foreigners. The tax system is lopsided and dominated by oil revenue which poses formidable challenges to the establishment of effective and efficient tax system.

Effective tax administration is an issue as old as taxation itself. The balancing act between maximizing tax revenues and minimizing the impact on the populace in which the state must engage was evident as early as $2350 \mathrm{BC}$. The responsibility shouldered by the government of any nation, particularly the developing nations, is enormous. The need to fulfill these responsibilities largely depends on the amount of revenue generated by the government through various means.

Taxation is one of the oldest means by which the cost of providing essential services for the generality of persons living in a given geographical area is funded. Globally, governments are saddled with the responsibility of providing some basic infrastructures for their citizens. Functions or obligations the government may owe her citizens include but are not restricted to: stabilization of the economy, redistribution of income and provision of services in the form of public goods.

Taxation is a major source of government revenue all over the world and governments use tax proceeds to render their traditional functions, such as: the provision of roads, maintenance of law and order, defence against external aggression, regulation of trade and business to ensure social and economic maintenance.. The primary function of a tax system is to raise enough revenue to finance essential expenditures on the goods and services provided by government; and tax remains one of the best instruments to boost the potential for public sector performance and repayment of public debt as posited by Okoye and Ezejiofor, (2014). A system of tax avails itself as a veritable tool that mobilizes a nation's internal resources and it lends itself to creating an environment that is conducive for the promotion of economic growth and development. Therefore, taxation plays a major role in assisting a country to meet its needs and promote self-reliance. In Nigeria, tax revenue has accounted for a small proportion of total government revenue over the years compared with the bulk of revenue needed for development purposes that is derived from oil (Oloidi\&Oluwalana, 2014). The desire of any government to maximize revenue from taxes collected from tax payers cannot be over-emphasized. This is because, as it well-known, the importance of tax lies in its ability to generate revenue for the government, influence the consumption trends and grow and regulate economy through its influence on vital aggregate economic variables. 
The revenue accruing to the Federal Government of Nigeria from taxation over the years has remained grossly insufficient to meet the expanding social and public spending required in fostering economic growth and development in the country (Asaolu, Olabisi, Akinbode, Alebiosu, 2018). The tax system is grossly inefficient as it is characterized by tax evasion, avoidance and record falsifications which have led to consistent low tax revenue inflow (Oyedele, 2019). Gross inefficiency and leakages have hampered the amount of revenue realized from tax sources over the years which has been affecting the economy negatively (Oyedele, 2019) as well as income per capita. The inability of the Federal Inland Revenue Service Board to ensure total compliance to tax rules by companies and bring all operational companies into the tax net has significantly limited the contribution of tax revenue to per capita income. Furthermore, the prevalence of tax evasion in the Nigeria tax system, has curtailed the amount of revenue collected from tax income, this in no doubt has effect on the government expenditure and inflation in the economy. Moreover, the revenue generation capacity of the nation's present tax administrative system is hampered by challenges such as paucity of data, inefficient monitoring and enforcement system, and corrupt practices (Okeke, Mbonu, Amahalu, 2018). There is a huge scale of corrupt practices prevalent in Nigeria tax administrative system, this tells to a reasonable extent that the economy is at a disadvantage position. However, given the ever increasing social and infrastructural expenditure needs of government, greater tax revenue will be needed to execute or sustain the required level of spending that can trigger economic growth. These shortcomings may be more evident where government's financing relies heavily on more distortionary taxes (e.g. direct taxes) and where public expenditure focuses on unproductive activities. The major problem lies in the procedures, machinery and approaches adopted in collection, assessment and compliance practices of tax.

This could be as a result of variation in geographical location, variables, methodology scope and statistical tools. For example, Nadeem, Azam and Shinwari (2015) analyzed the impact of tax revenues on economic growth of Pakistan and found a positive relationship between the study variables. Onakoya, Afintinni and Ogundajo (2017) used time series data to report a positive relationship between tax revenue and per capita income; Okeke, Mbonu and Amahalu (2018) found a positive relationship between tax revenue and economic development in Nigeria by employing augmented dickey-fuller test and regression analysis. On the other hand Sackey and Ojong (2014) employed multiple regression analysis to report a negative relationship between personal income tax and economic development in Nigeria; Ofoegbu, Akwu and Oliver (2016) employed ordinary least square to document a negative relationship between companies income tax and per capita income in Nigeria; Igbasan (2017) adopted co-integration analysis to document a negative relationship between the personal income tax and economic development in Nigeria.

Thus from the foregoing there is a clear evidence of a gap in economic development measurement, hence this present study bridged the gap by focusing exclusively on economic development index using per capita income as prior studies focused on Real Gross Domestic Product. Furthermore, in an attempt to filling the currency gap in knowledge, the scope of this present study covered a period of twenty (20) years spanning from 2000-2019 in order to establish contemporary empirical findings.

The main objective of this study was to examine the effect of Tax Revenue on Economic Development of Nigeria. The specific objectives were to: 
i. Examine the effect of Companies' Income Tax on Per Capita Income of Nigeria.

ii. Ascertain the effect of Petroleum Profit Tax on Per Capita Income of Nigeria.

\section{Review of related Literature}

\section{Tax Revenue}

Tax revenue is defined as the revenues collected from taxes on income and profits, social security contributions, taxes levied on goods and services, payroll taxes, taxes on the ownership and transfer of property, and other taxes (Sion, 2019). Tax revenue is the income that is gained by governments through taxation. Taxation is the primary source of income for a state. Revenue may be extracted from sources such as individuals, public enterprises, trade, royalties on natural resources and/or foreign aid (Moss, 2016). Total tax revenue as a percentage of GDP indicates the share of a country's output that is collected by the government through taxes. It can be regarded as one measure of the degree to which the government controls the economy's resources. The tax burden is measured by taking the total tax revenues received as a percentage of GDP. This indicator relates to government as a whole (all government levels) and is measured in million USD and percentage of GDP (Krugman, 2012).It gives a detailed report on revenue collected from different items like corporation tax, income tax, customs and excise duties, taxes on nation territories like land revenue, stamp registration etc. Taxes collected from both direct and indirect tax are considered in tax revenue (Brautigam, 2019).

\section{Companies Income Tax (CIT)}

Company income tax is a tax imposed by the Government on the income and profits of companies operating in the country. The law governing the administration of Companies Income Tax is the Companies Income Tax Act. The law which was first enacted in 1961 has undergone so many amendments, the latest being that of April, 2007. Companies Income Tax (CIT) is a tax on the profits of registered companies in Nigeria. It also includes the tax on the profits of foreign companies carrying on business in Nigeria. The tax is paid by limited liability companies inclusive of the public limited liability companies. It is therefore commonly referred to as the corporate tax (Onyeyiri, 2019). All public limited liability companies in Nigeria outside the Petroleum sector of the economy are required to pay income and education tax. The rate is $30 \%$ of total profit for income tax and $2 \%$ of assessable profit for education tax. Total profit is profit after deducting previous year losses carried forward and capital allowances. Assessable profit is obtained prior to deducting capital allowances. Resident companies are incorporated under the Companies and Allied Matters Act (CAMA) 2004. The administration of the Companies Income Tax is vested on the Federal Inland Revenue Service which used to be known as the Federal Board of Inland Revenue (FBIR) until the enactment of the Federal Inland Revenue Establishment Act in April, 2007 which scrapped the FBIR and replaced it with Federal Inland Revenue Service (Pwc, 2019). The current Tax rate in any year of assessment for a company in Nigeria is $30 \%$. The tax is payable on the profits accruing in, derived from, brought into or received in Nigeria. These profits are in relation to the following activities: Any trade or business carried out; Rent or any premium arising from a right granted any person for the use or occupation of any property; Dividends, interest, discounts, royalties, charges or annuities; Any source of annual profits not falling under any of the fore-goings; Fees, dues, and allowances for services rendered; Any amount of profits or gains arising from acquiring or disposing short-term money instruments like the federal government securities, Treasury Bills and Savings Certificates, Debenture Certificates and Treasury Bonds. Any amount deemed to be income 
or profit with respect to any benefit arising from a pension or provident fund under the Personal income tax act (Olumuyiwa, 2019).

Where in any year of assessment the ascertainment of total assessable profit from all sources of a company results in a loss, or where a company's ascertained total profits result in no tax payable or tax payable which is less than the minimum tax, there shall be levied and paid by the company a minimum tax as prescribed by subsection (2) of section 33 of CITA(Babatunde, 2019). The minimum tax to be levied and paid are as follows: If the turnover of the company is N500,000 or below and the company has been in business for at least four calendar years, the minimum tax shall be: $0.5 \%$ of gross profit; or $0.5 \%$ of net assets; or $0.25 \%$ of paid-up capital; or $0.25 \%$ of turnover of the company for the year; If the turnover is higher than N500,000, be whatever is payable as per any of the above, plus such additional tax on the amount by which the turnover is in excess of N500,000 at a rate which shall be $50 \%$ of the rate used above of $0.25 \%$ (Babatunde, 2019).

\section{Petroleum Profit Tax (PPT)}

PPT is a tax on the income of companies engaged in upstream petroleum operations in lieu of CIT. Petroleum profit tax (PPT) is a tax applicable to upstream operations in the oil industry. It is particularly relatedto rents, royalties, margins and profit sharing elements associated with oil mining, prospecting and exploration leases. It is the most important tax in Nigeria in terms of its share of total revenue contributing 95 and 70 percent of foreign exchange earnings and government revenue, respectively (Afuberoh\&Okoye, 2014).Petroleum operation as defined in the PPTA essentially involves petroleum exploration, development, production and sale of crude oil. The Petroleum Profit Tax is regulated by the Petroleum Profit Tax Act of 1959as amended by the Petroleum Profit Tax Act of 2007. Although the initial law was passed in 1959 to capture the first oil export made in that year (Okeke, Mbonu\&Amahalu, 2018). Section 8 of Petroleum Profit Tax Act (PPTA) states that every industry engaged in petroleum operations is under an obligation to render return, together with properly annual audited accounts and computations, within a specified time after the end of its accounting period. Petroleum profit tax involves the charging of tax on the incomes accruing from petroleum operations (Abdullahi, Madu\&Abdullahi, 2015). The importance of petroleum to the profitability of oil and gas firms in Nigeria gave rise to the enactment of a different law regulating the taxation of incomes from petroleum operations. The petroleum profit tax is charged, assessed and payable upon the profits of each accounting period of any industries engaged in petroleum operations during any such accounting period, usually one year (January to December) (Okeke, Mbonu\&Amahalu, 2018). The profits of a industries in relation to the accounting period is the aggregate of: (a)the proceeds of sale of all chargeable oil during that period;(b)the value of all chargeable oil disposed of in that period;(c)the value of all chargeable natural gas in that period; and all income of the industries of that period incidental to and arising from any one or more of its petroleum operations (i.e. winning or obtaining and transportation of petroleum or chargeable oil in Nigeria by or on behalf of a industries, for its own account by any drilling, mining, extracting or other like operations or process, not including refining at a refinery, in course of a business carried on by the industries engaged in such operations, and all other operations, incidental there to and any sale of or disposal of chargeable oil by or on behalf of the industries.

\section{Economic Development}


Economic development' is a process in which a nation is being improved in the sector of the economic, political, and social well-being of its people (Krueger \&Myint, 2019). Economic development is the process by which emerging economies become advanced economies. Economic development also refers to the process by which the overall health, well-being, and academic level the general population improves.During the development, there is a population shift from agriculture to industry, and then to services. A longer average life expectancy, for example, is one of the results of economic development. Improved productivity, higher literacy rates, and better public education, are also consequences (Sen, 2019). Economic development is all about improving living standards. Improved living standards refer to higher levels of education and literacy, workers' income, health, and lifespans. It is the process in which an economy grows or changes and becomes more advanced, especially when both economic and social conditions are improved. Economic development is the process in which people in a country become wealthier, healthier, better educated, and have greater access to good quality housing (Behrman, 2017).

\section{Empirical Review}

The extant reviewed literatures drawn from both developed and developing economies as being related to theme of this study is discussed as follows: Adegbie and Fakile (2011) assessed the relationship between petroleum profit tax and economic development of Nigeria. Primary and secondary data were used to collect the research data, while chi-square and multiple regression statistical models were used to analyze the results of the field work. The findings revealed that there is a very strong relationship between petroleum profit tax and economic development of Nigeria, tax avoidance and evasion are major hindrance to income growth in this sector, poor tax administration is a problem to effectiveness and efficiency of this source of income, and lack of corporate social responsibilities is causing unrest in the crude oil production zone.Ogbonna and Ebimobowei (2012) examined the impact of tax reforms on the economic growth of Nigeria from 1994 to 2009. The data collected were analyzed using relevant descriptive statistics and econometric models such as White test, Ramsey RESET test, Breusch Godfrey test, Jacque Berra test, Augmented Dickey Fuller test, Johansen test, and Granger Causality test. The results from the various test showed that tax reforms is positively and significantly related to economic growth and that tax reforms granger cause economic growth. Feng and Eko (2014)determined the relationship between tax revenue and economic growth of Hebei Province from 1978-2011 by the simple and amended tax multiplier effect theory and the polynomial distributed lag (PDL) model. The results showed that the negative impact of increase of tax revenue on economic growth may not be as serious as one might think and tax cuts would create more positive effects in Hebei Province. Akenbor and Arugu (2014) investigated state government taxation in Nigeria with a view to determine its impact on economic growth using the Central Bank of Nigeria (CBN) Statistical Bulletin for a period of 13 years (1999-2012). The data were analyzed with multiple regression analysis. The findings revealed that state government taxation has a significant impact on economic growth in Nigeria. Edame and Okoi (2014) examined the impact of taxation on investment and economic growth in Nigeria from 1980-2010. The ordinary least square method of multiple regression analysis was used to analyze the data. The annual data were sourced from the central bank of Nigeria statistical bulletin and NBS. The result of the analysis showed in conformity to a priori expectation because the parameter estimates of corporate income tax (CIT) and personal income tax (PIT) appears with negative signs, this means that an inverse relationship exist between taxation and investment. The economic implication of the result is that a one percent (1\%) increase in CIT will result in 
decrease in the level of investment in Nigeria. Ajani (2015) examined the petroleum profit tax Act, which is in fact one the many tax heads, under which different arms of the government levy charges to the petroleum industry. The field is populated by a winding mass of legislations, (both principal and subsidiary); directives from government and numerous parastatals, and many contractual and quasi-contractual arrangements. The major finding was that petroleum profits taxation system is a hopeless jumble, which requires an objective appraisal and therefore a reform that would ensure transparency and accountability in the interest of all stake holders. Ogbonna and Odoemelam (2015) investigated the impact of taxation on economic development of Nigeria proxied by the gross domestic product (GDP). The study further looked at the relation between companies income tax (CIT), petroleum profit tax (PPT) and gross domestic product in post-IFRS period. The data were analyzed using descriptive statistics, econometric model with the aid SPSS version 20. The results showed that a strong positive and significant relationship exist between economic development and Tax variables used. It also documented a decline in tax revenue in post IFRS period. Afrrev (2015) examined tax reforms in Nigeria with respect to value added tax (VAT). Afrrev highlighted the reasons for the replacement of sales tax with value added tax (VAT), yearly contributions of value added tax to the total revenue base of the nation and revealed that Value Added Tax (VAT) was designed to favour development at the lower tier level of government. Nur-Arifah, Abdul and Sahibzada (2016) identified the role and impact of tax in economic growth. The study used 27 selected Asian countries for 5 year time period (panel data). The relationship between the dependent variables (GDP per capita and FDI rate) and independent variables (individual income tax, corporate tax, and consumption tax) was investigated in order to identify the role of tax in economic growth. Descriptive analysis and regression analysis was adopted to analyze the data. The data were collected based on GDP per capita, FDI rate, corporate tax, individual income tax and consumption tax extracted from the information that has been published in the World Bank official websites. E-Views software was adopted to analyze descriptive correlation and regression analysis. A significant positive relationship was found between GDP per capita, FDI rate, corporate tax, individual income tax and consumption tax. Gylych, Abdulrahman and Abdurrahman (2016) examined the impact of tax reforms on the economic growth of Nigeria from 1986 to 2012. To achieve the objective of the study, relevant secondary data were collected from Central Bank of Nigeria publications, Federal Inland Revenue Service publications and the publications of Federal office of statistics, text book, published and unpublished thesis. Using the E-views Windows, the OLS regression results showed that tax reforms is positively and significantly related to economic growth and that tax reforms indeed causes economic growth. Onakoya, Babatunde and Afintinni, (2016) investigated the cointegration relationship between tax revenue and Economic growth in Nigeria from 1980 to 2013. Various preliminary tests including descriptive statistics, trend analysis, and stationary tests using Augmented Dickey Fuller (ADF) test were conducted. The Engle-Granger Cointegration test was employed to determine whether a long run relationship existed between the variables. The Vector Error Correction Model was employed to confirm the long run relationship and determine the short run dynamics between the variables. Findings indicated that a long run (but no short run) relationship existed between taxation and economic growth in Nigeria. The result also, revealed a significant positive relationship at 5\% level of significance between Petroleum profit tax, Company Income tax and economic growth, but a negative relationship between economic growth and customs and Excise Duties. Kalaš, Mirović andAndrašić (2017) provided an empirical approach to taxes and economic growth in the United States in the period 1996-2016. Correlation matrix reflects a strong and positive relationship between tax 
revenue growth and corporate income tax on the one side and gross domestic product growth, on the another side. The model showed a significant effect of tax revenue growth and social security contributions, while personal income tax and corporate income tax do not have a significant impact on gross domestic product growth. Interestingly, personal income tax as the main tax form in the tax structure of the United States has no significant impact on economic growth compared to social security contributions which percentage share is lesser. Aminu and Eluwa (2017) examined the impact of tax reform policy on revenue generation of the Federal Government of Nigeria. The primary objective of the study was to prepare a case study on tax policy reforms in Nigeria, with the specific objectives of examining the main tax reforms in the country, highlighting tax revenue profile and contributions of the three categories of taxes identified as personal, company and custom duties to the total revenue collection. The techniques of data analysis adopted for the empirical study were the Analysis of Variance Method and the Schaffer's Multiple Comparison techniques. Neway, Kenenisa and Woldemicael (2018) identified determinants of tax revenue in Ethiopia by using secondary data and multiple variable regression model using OLS method. Quantitative research method was employed on time series data set for the years 1999/00 to 2015/16. Both descriptive statistics and econometric tools were employed to analyze and present the data collected from concerned bodies. The finding revealed that, industry sector share to GDP, per capita income and trade openness as measured by share of export and import to GDP have significant positive effect on tax revenue whereas; agriculture sector share to GDP and annual rate of inflation have significant and negative effect on tax revenue as measured by share of tax revenue to GDP. Yahaya and Bakare (2018) evaluated the effect of petroleum profit tax and company income tax on Nigerian economy growth. Fully Modified Least Square (FMOLS) Regression Technique was used to estimate the model over a 34 year period (19812014) while Augmented Dickey Fuller Unit Root Test and Single Equation Co-integration Test were carried out. It was found that petroleum profit tax (PPT) and company income tax (CIT) have positive significant impact on gross domestic product (GDP) in Nigeria with the Adjusted $\mathrm{R}^{2}$ of $87.6 \%$ which directly enhanced growth in Nigeria. The study concluded that PPT and CIT served as the major source of revenue to the Nigeria economy, and contributes to the growth of Nigeria economy. Asaolu, Olabisi, Akinbode andAlebiosu (2018) examined the relationship between tax revenue and economic growth in Nigeria. The results of the study showed that VAT and CED had a significant relationships with economic growth $(\mathrm{p}<0.05)$, while CIT has negative significant relationship with economic growth $(\mathrm{P}<0.05)$. However, PPT had no significant relationship with economic growth. The study concluded that the role of taxation in nation's building is irreplaceable. Taxation remains a strong socio political and economic tool for economic prosperity. It is therefore recommended that government should engage in a complete re-organization of tax administrative machinery to reduce incidence of tax evasion and avoidance to the barest minimum in order to improve tax revenue and bring more people and establishments into the tax net. Also, tax revenue should be judiciously utilized to provide enabling environment for business survival and economic growth in Nigeria. Olaoye and Ayeni (2019) examined value added tax and customs duties on revenue generation in Nigeria. Secondary data were sourced from Federal Inland Revenue Service (FIRS) ranging from 2000 to 2016. Autoregressive Distributed Lag (ARDL) and Granger causality tests were used as the estimation techniques. The findings of the study revealed that the F-statistics value was 2.883868 which is lesser than both the lower bound and the upper bound values of 3.79 and 4.85 respectively at the 5percent level of significance which implies that there is no long-run relationship among value-added tax, customs duties and revenue generation. It was equally revealed that there is no causality among value-added 
tax, customs duties, and revenue generation. Omondi (2019) analyzed the effect of custom and excise duties on economic growth in Kenya for the period 1973 to 2010. The study was motivated by two developments. First, by the inconsistency in existing empirics and secondly by the wide knowledge gap occasioned by the paucity of empirical literature on Kenya. Therefore, the study attempted to reconcile the different positions and also close the knowledge gap. The study adopted a correlation research design based on its ability determine the strength and direction of relationships between variables while the theoretical framework was anchored on endogenous growth model.

\section{METHODOLOGY}

\section{Research Design}

The aim of the study was to determine the effect of tax revenue on economic development of Nigeria. The research is a causal design based on an in-depth analysis of the relationship between tax revenue and economic development in Nigeria from 2000-2019. Consequent upon this, Ex-post Facto research design was adopted.

The thirty-six (36) states of the Federal Republic of Nigeria including the Federal Capital Territory, Abuja, constituted the population of this study.

The analysis of data for this study was done based on the data collected from publications and statistical bulletins of CBN, FIRS and NBS. Both the dependent and independent variables were computed from the data extracted from the publications of the CBN, FIRS, NBS and other relevant sources.

\subsection{Model Specification}

To measure the relationship between tax revenue on economic development, this study adapted the model of Okeke, Mbonu, and Amahalu (2018):

$\mathrm{SE}=f(\mathrm{PPT}, \mathrm{PIT}, \mathrm{VAT})+\mathrm{u}_{\mathrm{t}}$

Where:

$\mathrm{SE}=$ School Enrolment

PPT $=$ Petroleum Profit Tax

PIT = Personal Income Tax

$\mathrm{VAT}=$ Value Added Tax

Expressing the relationship in linear form using the variables, the following estimating equations were arrived at:

$$
\begin{array}{llllll}
\mathrm{PCI}_{\mathrm{t}}=\beta_{\mathrm{o}}+\beta_{1} \mathrm{CIT}_{\mathrm{t}}+\mu_{\mathrm{t}} & - & - & - & - & \text { Model 1 } \\
\mathrm{PCI}_{\mathrm{t}}=\beta_{\mathrm{o}}+\beta_{1} \mathrm{PPT}_{\mathrm{t}}+\mu_{\mathrm{t}} & - & - & - & - & \text { Model 2 }
\end{array}
$$

Where:

$\beta_{\mathrm{o}}=$ Intercept

$\beta_{1}=$ Coefficient of Tax Revenue

$\mathrm{PCI}_{\mathrm{t}}=$ Per Capita Income for period $\mathrm{t}$

$\mathrm{CIT}_{\mathrm{t}}=$ Companies' Income Tax for period $\mathrm{t}$

$\mathrm{PPT}_{\mathrm{t}}=$ Petroleum Profit Tax for period $\mathrm{t}$

$\mu_{\mathrm{t}} \quad=\quad$ error term for period $\mathrm{t}$

$t$ denotes the annual time-period

\section{Decision Rule}

Accept the alternative hypothesis, if the P-value of the test is less than 0.05 . Otherwise reject. 
Data Presentation and Analysis

\section{Data Presentation}

Table 1: Descriptive Statistics

$\begin{array}{cccc} & \text { PCl } & \text { CIT } & \text { PPT } \\ \text { Mean } & 3.6364 & 11.5782 & 12.1038 \\ \text { Median } & 3.6832 & 11.7809 & 12.1306 \\ \text { Maximum } & 3.7821 & 12.1487 & 12.5053 \\ \text { Minimum } & 3.3483 & 10.7441 & 11.3510 \\ \text { Std. Dev. } & 0.1449 & 0.4402 & 0.3439 \\ \text { Skewness } & -0.6359 & 0.5891 & 0.7501 \\ \text { Kurtosis } & 2.0339 & 1.9651 & 2.5179 \\ \text { Jarque-Bera } & 7.1259 & 12.495 & 19.062 \\ \text { Probability } & 0.0004 & 0.0000 & 0.0000 \\ \text { Sum } & 72.7272 & 231.5647 & 242.0760 \\ \text { Sum Sq. Dev. } & 0.3987 & 3.6810 & 2.2472 \\ \text { Observations } & 20 & 20 & 20\end{array}$

Source: E-Views 10, Descriptive Output 2020

From table 1, the observation is 30 which is the study thirty years period of interest from 2000-2019. The standard deviations in the study are $0.145,0.44,0.344,0.382,0.351$ and 0.577 . For such distributions, it is the case that $14.5 \%, 44 \%, 34.4 \%, 38.2 \%, 35.1 \%$ and $57.7 \%$ of values are less than one standard deviation (1SD) away from the mean values of PCI, CIT, PPT, CED, VAT and PIT respectively. Skewness and Kurtosis are contained in Jarque-Bera. Positively skewed is an indication of a rise in revenue while negatively skewed is an indication of loss or backwardness. It is delineated in table 4.1 that CIT, PPT and PIT are positively skewed at the values of $0.5891,0.7501$ and 0.5647 respectively. On the other hand, PCI (-0.6359), CED (-0.6010), VAT (-0.6036) are negatively skewed. The probability values for the Jarque-bera test shows that PCI, CIT, PPT and VAT are significantly normally distributed since their probability values of $0.0004,0.0000,0.0000$ and 0.0000 respectively are less than $5 \%$. While the probability values of CED (0.2615) and PIT (0.2887) are not significantly normally distributed because their probability values are greater than $5 \%$. 


\section{Test of Hypotheses}

\section{Test of Hypothesis I}

Ho1: Companies' Income Tax has no significant effect on Per Capita Income of Nigeria.

$\mathbf{H}_{1}$ : Companies' Income Tax has significant effect on Per Capita Income of Nigeria.

\section{Table 2 Ordinary Least Square regression analysis testing the effect of CIT on PCI}

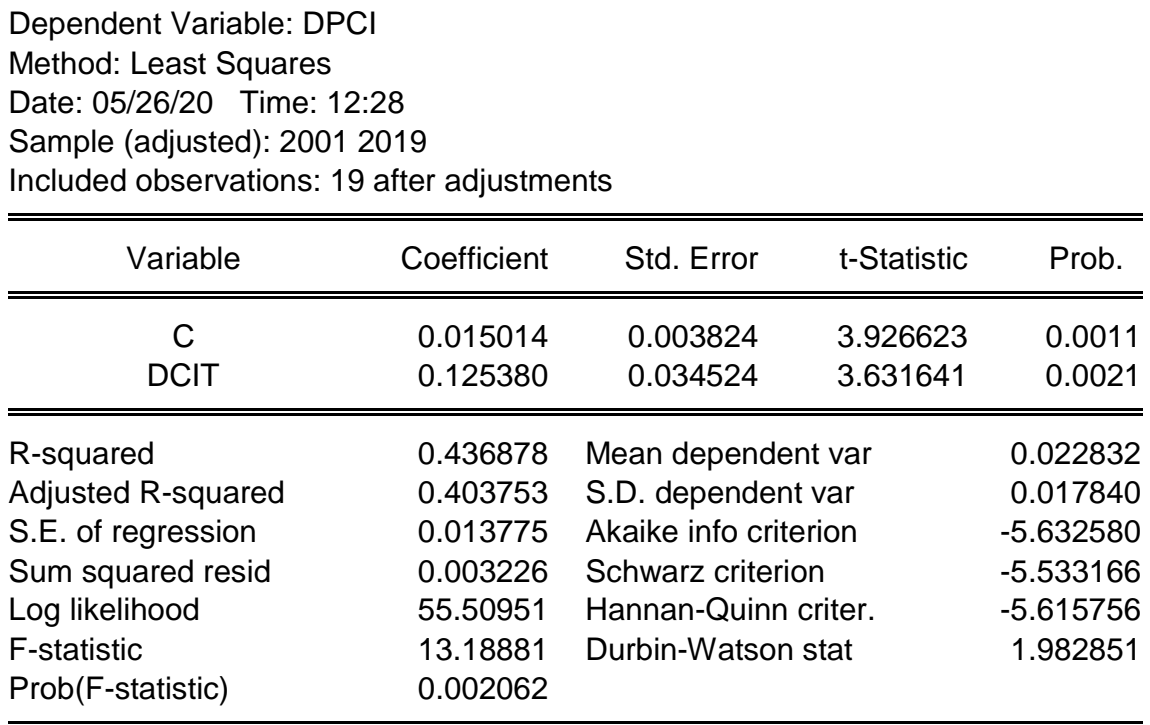

Source: E-Views 10 Regression Output, 2020

\section{Interpretation of Regression Coefficient Result}

The following regression equation was obtained from table 4.4:

\section{$\mathrm{DPCI}=0.015014+0.125380 \mathrm{DCIT}$}

Using the above model, it is possible to determine the relationship between DPCI and DCIT. Holding all other factors constant, an increase in one unit of the independent variable (CIT) results into a corresponding increase in one unit of PCI, this means that a positive relationship exists between the explanatory variable (CIT) and PCI. The slope coefficient shows that the probability value: $\mathrm{P}\left(\mathrm{x}_{1}=0.0021<0.05\right)$ is less than the critical $\mathrm{P}$-value of 0.05 . This implies that CIT has a significant positive relationship with PCI at 5\% significant level. Results in table 4.4 also indicated that the R-squared for the model is 0.437 , meaning that the regression model used for this study is a good predictor. The independent variable explained $43.7 \%$ of the variation in PCI. Only 56.3\% of variation in PCI is not explained by the regression model. The Durbin-Watson value of 1.982851 indicates the absence of serial correlation in the model.

\section{Decision:}

The P-Value of the test Prob(F-statistic) $=0.002062$ is less than the $\alpha$-value of 0.05 ; therefore $\mathrm{H}_{1}$ is accepted and Ho is rejected. Since the p-value of the test is less than 0.05 , then there exists enough evidence to reject the null hypothesis and conclude that companies' income tax has a significant positive effect on per capita income of Nigeria at 5\% level of significance. 


\section{Table 3: Granger Causality Test showing the Causality between CIT and PCI}

Pairwise Granger Causality Tests

Date: 05/26/20 Time: 12:29

Sample: 20002019

Lags: 2

\begin{tabular}{lccc}
\hline \hline Null Hypothesis: & Obs & F-Statistic & Prob. \\
\hline \hline DCIT does not Granger Cause DPCI & 17 & 5.45456 & 0.0442 \\
DPCl does not Granger Cause DCIT & & 7.05813 & 0.0045 \\
\hline \hline
\end{tabular}

Source: E-Views 10 Causality Output, 2020

\section{Decision Rule:}

If the F-value of the causality test is statistically significant at $5 \%$, then causality is established. This implies that the Independent variable granger causes the dependent variable. Hence, $\mathrm{H}_{1}$ is accepted, otherwise accept Ho.

\section{Interpretation of Diagnostic Result}

The result of the Granger causality test in table 4.5 indicates a bi-directional relationship between PCI and CIT at 5\%. It implies that CIT granger causes PCI at the probability value of 0.0442, while, on the other hand PCI also granger causes CIT at 0.0045. The Granger Causality test result reveals evidence of casual relationship between CIT and PCI, thereby confirming the hypothesis that CIT has a statistically significant relationship with PCI in Nigeria.

\section{Test of Hypothesis II}

$\mathrm{Ho}_{2}$ : Petroleum Profit Tax has no significant effect on Per Capita Income of Nigeria.

$\mathbf{H}_{2}$ : Petroleum Profit Tax has significant effect on Per Capita Income of Nigeria.

Table 4 Ordinary Least Square regression analysis testing the relationship between PPT and PCI

Dependent Variable: DPCI

Method: Least Squares

Date: 05/26/20 Time: 12:51

Sample (adjusted): 20012019

Included observations: 19 after adjustments

\begin{tabular}{lrlrr}
\hline \hline \multicolumn{1}{c}{ Variable } & Coefficient & Std. Error & t-Statistic & Prob. \\
\hline \multicolumn{1}{c}{ C } & 0.022687 & 0.004315 & 5.258161 & 0.0001 \\
\multicolumn{1}{c}{ DPPT } & 0.003103 & 0.020396 & 7.152124 & 0.0000 \\
\hline \hline R-squared & 0.481359 & Mean dependent var & 0.022832 \\
Adjusted R-squared & 0.457384 & S.D. dependent var & 0.017840 \\
S.E. of regression & 0.018344 & Akaike info criterion & -5.059683 \\
Sum squared resid & 0.005721 & Schwarz criterion & -4.960268 \\
Log likelihood & 50.06699 & Hannan-Quinn criter. & -5.042858 \\
F-statistic & 24.03142 & Durbin-Watson stat & 1.981340 \\
Prob(F-statistic) & 0.000000 & & \\
\hline \hline
\end{tabular}

Source: E-Views 10 Regression Output, 2020 


\section{Interpretation of Estimated Regression Coefficients}

The relationship between petroleum profit tax and per capita income in Nigeria was evaluated based on the result of table 4.8. From table 4.8, PPT with a positive co-efficient of 0.003103 has a significant effect on PCI as indicated by the t-statistic of 7.152124 and its associated probability value of 0.0000 . The $\mathrm{R}$ squared which examines the extent to which the predictors combine to explain the variations in the dependent variable (PCI) shows that the R Squared figure of 0.48 indicates that, reliance on this model will account for $48 \%$ of the variations in the dependent variable (PCI). The Durbin-Watson value of 1.981340 buttressed the fact that the model does not contain auto-correlation, thereby, making the regression fit for prediction purpose. The analysis resulted in F-value of 24.03142 with corresponding p-value of 0.000000 .

\section{Decision}

Since the p-value of the test at 0.000000 is less than the critical significant value of 0.05 $(5 \%)$, thus $\mathrm{H}_{1}$ is accepted and Ho rejected. This implies that petroleum profit tax has a significant positive effect on per capita income in Nigeria at 5\% level of significance.

\section{Table 5: Granger Causality Test showing the Causality between PPT and PCI}

\begin{tabular}{|c|c|c|c|}
\hline $\begin{array}{l}\text { Pairwise Granger Causality Tests } \\
\text { Date: 05/26/20 Time: 12:54 } \\
\text { Sample: } 20002019 \\
\text { Lags: } 2\end{array}$ & & & \\
\hline Null Hypothesis: & Obs & F-Statistic & Prob. \\
\hline DPPT does not Granger Cause DPCI & 17 & 5.87117 & $\begin{array}{l}0.0331 \\
0.3578\end{array}$ \\
\hline
\end{tabular}

Source: E-Views 10 Causality Output, 2021

\section{Interpretation of Diagnostic Result}

The result of the Granger causality test in table 4.9 above indicates a uni-lateral relationship between PCI and PPT at 5\%. It implies that PPT granger causes PCI at the probability value of 0.0331 , the causation runs from PPT to PCI at $5 \%$ level of significance and does not run in the reverse sense. The Granger Causality test result reveals evidence of casual relationship between PPT and PCI.

\section{Discussion of Findings}

This study covers the statistical analysis and interpretation of fitting regression models between tax revenue and economic development of Nigeria. The slope coefficient for hypothesis 1 showed that the probability value: $\mathrm{P}\left(\mathrm{x}_{1}=0.0021<0.05\right)$ is less than the critical $\mathrm{P}$ value of 0.05 . This implies that CIT has a significant positive relationship with PCI at 5\% significant level. Results of hypothesis 1 also indicated that the R-squared for the model is 0.437 , meaning that the regression model used for this study is a good predictor. The independent variable explained $43.7 \%$ of the variation in PCI. Only $56.3 \%$ of variation in PCI is not explained by the regression model. The Durbin-Watson value of 1.982851 indicates the absence of serial correlation in the model.

The findings in hypothesis II demonstrated that PPT with a positive co-efficient of 0.003103 has a significant effect on PCI as indicated by the t-statistic of 7.152124 and its associated 
probability value of 0.0000 . The $\mathrm{R}$ squared which examines the extent to which the predictors combine to explain the variations in the dependent variable (PCI) shows that the R Squared figure of 0.48 indicates that, reliance on this model will account for $48 \%$ of the variations in the dependent variable (PCI). The Durbin-Watson value of 1.981340 buttressed the fact that the model does not contain auto-correlation, thereby, making the regression fit for prediction purpose.

\section{Conclusion and Recommendations}

This study assessed the effect of tax revenue on economic development of Nigeria for twenty (20) years period ranging from 2000-2019. Existing literature shows that researchers are yet to reach a consensus about the effect oftax revenue on economic development. Therefore, the effect is yet to be well established. In order to avoid spurious estimates, the unit roots of the series were verified using Augmented Dickey-Fuller (ADF) technique after which Granger Causality, were conducted. Data analysis revealed that companies' income tax has a significant positive effect on per capita income of Nigeria; petroleum profit tax has a significant positive effect on per capita income of Nigeria.

\section{Recommendations}

Based on the conclusion and findings of this study, the following were suggested:

1. To maximize the positive relationship between company income tax and economic development, there is need for application of information technology which is seen as the hallmark of the 21st century in all tax offices in Nigeria thereby making it possible for tax payers and tax authorities to declare uniform and consistent claims to avoid tax evasion in the country.

2. Considering the positive relationship between petroleum profit tax and economic development, federal government should underpin public financial management reforms, strengthen supervisory and transparency practices, improve tax administration, and fight tax evasion. 


\section{References}

Abdullahi, U., Madu I. \&Abdullahi, F. (2015).Evidence of petroleum resources on Nigerian economic development.Business and Economics Journal, 6(2), 11-18.

Adegbie, F.F., \&Fakile, A.S. (2011). Petroleum profit tax and Nigeria economic development.International Journal of Research In Computer Application \& Management, 1 (1), 11-18.

Afuberoh, D. \&Okoye, E. (2014). The impact of taxation on revenue generation in Nigeria: A study of federal capital territory and selected states. International Journal of Public Administration and Management Research (IJPAMR), 2(2), 22-47.

Akenbor, C.O., \&Arugu, L.O. (2014).State government taxation: Empirical evidence from Nigeria.The Business \& Management Review, 4(3), 63-71.

Aminu, A.A., \&Eluwa, D.I. (2017). The impact of tax reforms on government revenue generation in Nigeria. Journal of Economic and Social Development, 1(1), 1-10.

Asaolu, T.O., Olabisi, J., Akinbode, S.O., \&Alebiosu, O.N. (2018).Tax revenue and economic growth in Nigeria.Scholedge International Journal of Management \& Development, 05(07), 72-85.

$$
\mathrm{F}
$$

(2019).Understanding

companies

income tax.https://guardian.ng/features/understanding-companies-income-tax/. Retrieved $24 / 05 / 2019$

Behrman, J.R. (2017). Economics of development.International Encyclopedia of the Social \& Behavioral Sciences, 4(3), 111-119.

Brautigam, D. (2019). Building leviathan: Revenue, state capacity, and governance.Institute of Development Studies.33(4), 16-24.

Edame, G.E., \&Okoi, W.W. (2014).The impact of taxation on investment and economic development in Nigeria.Academic Journal of Interdisciplinary Studies.3(4).209-218.

Feng, Y., \&Eko, S. (2014). The relationship between tax revenue and economic growth of Hebei Province based on the tax multiplier effect.Global Economy and Finance Journal, 7(2), 1-18.

Gylych, J., Abdulrahman, S., \& Abdurrahman, I. (2016). The impact of tax reforms and economic growth of Nigeria. The Empirical Economics Letters 15(5), 30-40

Igbasan (2017).Tax revenue and economic growth of Nigeria. A dissertation submitted to Babcock University, 24-56.

Ihendinihu, J.U., Jones, E., \&Nwaiwu, J.N. (2014). Total revenue and economic growth in Nigeria: Empirical evidence. Journal of Emerging Trends in Economics and Management Sciences (JETEMS) 6(1), 40-46.

Kalaš, B., Mirović, V., \&Andrašić, J. (2017).Estimating the impact of taxes on the economic growth in the United States.Economic Themes, 55(4), 481-499.

Krugman, P. (2012). More Laffering.The New York Times.

Krugman, P.(2013). The new growth fizzle. New York Times.

Matallah, A., \&Matallah, S. (2017). Does fiscal policy spur economic growth? Empirical

Nadeem, I., Azam, M.F., \&Shinwari, S. (2015). Empirical analysis of tax revenues and its impact on economic growth of Pakistan. Journal of Economics and Sustainable Development, 6(1), 110-117.

Neway, G., Kenenisa, L.D., \&Woldemicael, S. (2018). Determinants of tax revenue in Ethiopia.Economics, 6(1),58-64.

Nur-Arifah, B.S., Abdul, B., \&Sahibzada, M.H. (2016). The role of tax on economic growth. International Journal of Accounting \& Business Management 4(2), 232-250. 
Ofoegbu, G.N., Akwu, D.O., \& Oliver, O .(2016). Empirical analysis of effect of tax revenue on economic development of Nigeria.International Journal of Asian Social Science, Asian Economic and Social Society, 6(10), 604-613.

Ogbonna, G. N., \&Ebimobowei, A (2012). Impact of tax reforms and economic growth: A time series analysis. Current Research Journal of Social Sciences, 4(1), 62-68.

Ogbonna, G., \&Odoemelam, N. (2015).Impact of taxation on economic development of Nigeria:

2000-2013.

https://www.researchgate.net/publication/305333001_impact_of_taxation_on_econo mic_development_of_nigeria_2000-2013

Okeke, M.N., Mbonu, C.M., \&Amahalu, N.N. (2018).Effect of tax revenue on economic development in Nigeria.International Journal of Research in Business, Economics and Management, 2(4), 25-61.

Okoye, P.V. C. \&Ezejiofor, R. A. (2014).The impact of e-taxation on revenue generation in Enugu, Nigeria. International Journal of Advanced Research, 2(2), 449-458.

Olaoye, C.O., \&Ayeni, O.F. (2019).Oloidi, G.A., \&Oluwalana, L.O. (2014). Another approach to evaluating the productivity of value Added tax in Nigeria. Developing Country Studies, 4(15), 39-45.

Olumuyiwa, B. (2019). Company income tax.https://www.legit.ng/1179976-how-calculatecompany-income-tax-nigeria.html. retrieved 09/06/2019

Omondi, B.O. (2019). The effect of custom and excise duties on economic growth in Kenya.International Journal of Scientific and Research Publications, 9(1), 530-546.

Onakoya, A.B., \&Afintinni, O.I. (2016).Taxation and economic growth in Nigeria.Asian Journal of Economic Modelling, 4(4), 199-210.

Onakoya, A.B., Afintinni, O.I., \&Ogundajo, G.O. (2017).Taxation revenue and economic growth in Africa.Journal of Accounting and Taxation, 9(2), 11-22.

Onyeyiri, U. (2019). Taxation of companies under Nigeria's companies income tax Act 2011,http://www.qeeva.com/taxation-companies-nigerias-companies-income-tax-act2011/. Retrieved 29/06/2019.

Oyedele, T. (2019).The personal income tax (amendment) act 2011: Implementation and matters arising.https://www.pwc.com/ng/en/pdf/pita-amendment-march-2012.pdf Retrieved 14/04/2019.

Pwc. (2019).Taxes on corporate income.http://taxsummaries.pwc.com/ID/Nigeria-CorporateTaxes-on-corporate-income. Retrieved 06/04/2019.

Sackey, J.A., \&Ojong, N.O. (2014). Tax revenue structure and its effect on economic growth.Archives of Applied Science Research, 6(1), 209-222.

Sen, A.K. (2019). What is economic development? Definition and examples.https://marketbusinessnews.com/financial-glossary/economicdevelopment/Retrieved 09/03/2019.

Sion, B. (2019). DVLA sets pace for public sector, Wales Online, Retrieved 21 March, 2019

Tomljanocich, M. (2014).The role of state fiscal policy in state economic growth. Journal of Contemporary Economic Policy, 22(3), 318-330.

Yahaya, K.A., \&Bakare, T.O. (2018).Effect of petroleum profit tax and companies income tax on economic growth in Nigeria. Journal of Public Administration, Finance and Law, 1(3)100-121. 